\title{
A democracia e seus inimigos!
}

Francisco José Soares Teixeira

\section{A missão civilizadora do colonialismo}

J PREFÁCIO à primeira edição alemã ficuldades que poderia apresentar a leitura do primeiro capítulo, Marx acrescenta que pressupõe leitores desejosos de aprender algo novo e, portanto, dispostos a pensar por conta própria. Domenico Losurdo enquadra-se nessa categoria. É um marxista que pensa com os fundadores do materialismo histórico, não para repetir simplesmente o que aprendeu com eles, mas, sim, na condição de discípulo que não se deixa anular diante da autoridade dos seus mestres. Em $\mathrm{Li}$ beralismo. Entre civilização e barbárie, caminha com eles, obviamente, mas com a autonomia de quem sabe abrir novos caminhos, corrigir o que lhe parece necessário e, assim, afirmar-se como leitor digno de Marx e de Engels.

Por isso, não teme em afirmar que o jovem Marx foi precipitado ao definir "os Estados Unidos como 'o país da mais acabada emancipação política’, ou ainda como 'o mais perfeito exemplo de Estado Moderno', que assegura o domínio da burguesia sem excluir a priori nenhuma classe social do gozo dos direitos políticos".

Para o autor de Liberalismo..., Marx fez vista grossa à discriminação censitária racial praticada pelos ianques. Mais ainda o fez Engels ao celebrar com entusiasmo a anexação da Califórnia pelos Estados Unidos. Não se deu conta, diz Losurdo, de que tal exaltação fazia eco à ideologia do manifest destiny. Em nome do advento do socialismo, o autor da Dialética da natureza não se continha de esperanças. Sem medir os adjetivos, aplaudiu a derrota dos "indolentes mexicanos", condição necessária, segundo assim entendia, para a transformação daquele país numa sociedade civilizada, governada, portanto, por relações capitalistas de produção.

Para não deixar seu leitor com dúvidas, Losurdo convida-o para acompanhálo na leitura que faz de Engels. Deixa-o expressar, em alto bom som, que, "graças ao 'valor dos voluntários americanos', 'a esplêndida Califórnia foi arrebatada aos indolentes mexicanos, que não sabiam que fazer dela'; aproveitando-se das novas e gigantescas conquistas, 'os enérgicos ianques' deram novo impulso à produção e circulação de riquezas, ao 'comércio', à difusão da 'civilização'”.

Seriam os fundadores do materialismo histórico indiferentes às dores e aos sofrimentos dos "povos bárbaros" (índios, negros, hindus etc.), que ainda viviam à margem do mundo civilizado? À primeira vista, tudo indica que sim. Prova disso oferece Losurdo ao comentar a veemência com que Marx celebra a invasão da Índia pelos ingleses. Sem nenhum constrangimento moral, o autor de $O$ capital afirma que

“a Índia não podia fugir ao destino (fate) e ser conquistada"; e por outro lado, a humanidade pode cumprir o seu destino (destiny) sem uma profunda revolução nas relações sociais da Ásia? E a Inglaterra conquistadora que leva a efeito na Índia “a mais 
grandiosa e, para dizer a verdade, a única revolução social que a Ásia jamais conheceu".

Marx certamente não é um cínico empedernido, alheio à miséria dos povos explorados. Losurdo sabe disso muito bem, quando lhe concede a palavra para dele ouvir que o "capital nasce escorrendo sangue e lama por todos os poros, da cabeça aos pés”. Mas nem por isso o jovem Marx se deixou tomar por sentimentos piedosos. Convicto de que a humanidade não poderia "cumprir a sua missão sem uma verdadeira revolução do estado social na Ásia”, vale-se de Goethe para dizer que não lamentava "os estragos, pois os frutos são prazerosos". Leitor de Hegel, aprendeu que a história universal não é uma aventura romântica, "viagens de cavaleiros errantes". Essa idéia aparece com toda força no Manifesto Comunista. Seus autores viam o mundo civilizado como "o instrumento inconsciente da História”, ao qual cabia a tarefa de realizar o trabalho sujo: varrer da terra todas "as relações sociais antigas e cristalizadas, com seu cortejo de concepções e de idéias secularmente veneradas".

A história encarregou-se de mostrar que Marx e Engels estavam errados. Losurdo diz por quê: abraçaram uma concepção fatalista da evolução social, que traz em seu seio um eco vibrante da filosofia liberal burguesa. Por essa razão, não teme afirmar que eles foram contaminados pelo preconceito iluminista, o qual via a tradição como um mundo povoado de mitos, fantasias e feitiçaria, que mantinha o homem num estado de menoridade indigno de criaturas dotadas de razão. Como os Iluministas, os autores do Manifesto Comunista defendiam a tese de que a tradição nada tem a en- sinar, devendo, portanto, ser exorcizada e sepultada sob os escombros do desenvolvimento das forças produtivas. Estariam, assim, justificados todos os crimes e atrocidades, cometidos em nome da civilização? É-se tentado a concordar. Para Losurdo, contudo, isso seria o mesmo que dar uma carta branca às metrópoles coloniais, outorgando-lhes direito de invadir e saquear a periferia capitalista.

Tocqueville, autor da Democracia na América, narra que os colonizadores da Nova Inglaterra julgavam que as terras daquele país estavam reservadas para eles, os quais, em nome de Deus, tomaram-nas dos indígenas - essa pobre e ignorante gente que não sabia o que fazer com elas. Por isso, aquela imensidão de terras, tão bem preparadas para o desenvolvimento do comércio e da indústria, não poderia permanecer nas mãos desse povo bárbaro. Afinal, quis Deus revelar ao branco, não ao índio, os segredos da agricultura.

De certa forma, o pensamento de Marx estaria muito próximo do de Tocqueville, segundo Losurdo, que ressalta o fato de que Marx, quando

define os EUA como o "país da emancipação política realizada", ou então como "exemplo mais perfeito de Estado moderno", que assegura o domínio da burguesia sem excluir a priori nenhuma classe social do gozo dos diretos políticos", é claro que procede a esta definição sem ter em conta a escravidão dos negros ou a sorte dos índios; não parece dar-se conta o fato de que a discriminação censitária passa nesse país através da discriminação racial. Nesse sentido, Marx pouco se distingue de Tocqueville. E é nos ambientes liberais do seu tempo que também faz pensar o 
alto reconhecimento do Manifesto Comunista pela burguesia da metrópole capitalista que "arrasta todas as nações, mesmo as mais bárbaras, para a civilização" e que, por meio das suas conquistas coloniais, cumpre a tarefa, aliás a "missão (mission), de criar o mercado mundial [...]"

Não só os Estados Unidos e a Inglaterra são vistos como "instrumentos inconscientes da História”. Losurdo constata, com base num artigo escrito em 1849, que traz o sugestivo título Paneslavismo democrático [Der demokratische Panslawismus], que Engels atribui à Alemanha função semelhante. Comenta que

o papel dos EUA desempenhado no continente americano, Engels parece pretender atribuí-lo à Alemanha na Europa central, enquanto o lugar do México parece ser ocupado pelas "naçõezinhas" (Nationchent) eslavas "que nunca tiveram história" e que só podem alcançar a "civilização" graças a um jugo estrangeiro.

As lições que Losurdo tira dessa concepção de Marx e Engels são ricas de ensinamentos políticos. A idéia da missão civilizadora de uma raça superior contaminou os partidos da social-democracia. Bernstein, por exemplo, em nome do progresso, abraça o social-darwinismo e o leva ao extremo, para defender a tese de que

"todas as raças fortes, todos os sistemas econômicos sólidos, têm a tendência para se alargarem e expandirem com a sua civilização. Este impulso expansionista tem sido em todos os tempos o mais poderoso fator de progresso". "Raças fortes" aqui é sinônimo de raças civilizadas, enquanto na vertente oposta vemos opor-se uma inútil e retrógrada resistência por parte dos povos não civilizados, e até - note-se bem - "incapazes de se civilizarem": dado que "se insurgem contra a civilização": têm de ser combatidos também pelo movimento operário.

Losurdo poderia ter avançado um pouco mais, para constatar que a socialdemocracia internacional, com honrosas exceções, justificou e facilitou a carnificina de dez milhões de seres humanos durante a Primeira Guerra Mundial, em nome de pretensas razões de defesa nacional. Os governos social-democratas, ou com a participação da social-democracia, organizaram ou defenderam guerras na Indochina, na Malásia, na Indonésia e na Argélia. Foram mais longe ainda. Defenderam práticas de torturas e limitaram as liberdades democráticas na Índia, na Indonésia, no Egito, no Iraque e em Cingapura. Protegeram o regime do apartheid na África do Sul. Participaram da guerra fria, além de se tornarem cúmplices das políticas imperialistas. Em nome do grande capital, apoiaram e organizaram as políticas de austeridade monetárias e fiscais, que tiveram como conseqüência o desmantelamento do Estado social, que ajudaram a construir.

\section{Universalismo e recolonização}

Bernstein não está muito distante de John Stuart Mill, para quem,

O despotismo é uma forma legitima de governo quando se lida com bárbaros; desde que o fim seja o seu progresso e os meios sejam justificados pela sua real consecução. A liberdade, como princípio, não é aplicável em nenhuma situação que anteceda o momento em que os homens se tenham tornado capazes de melhorar através da livre discussão entre iguais. 
Até então, não haverá nada para eles, salvo a obediência absoluta a um Akbar ou a um Carlos Magno se tiverem a sorte de encontrá-los.

Menos ainda está do amigo da Sociedade Aberta, Karl Popper. Esse democrata convicto, referindo-se às ex-colônias, lamenta: "'libertamos estes estados depressa demais e de maneira demasiada simplista'; é como 'deixar um orfanato entregue a ele mesmo'”.

Essas duas últimas citações, extraídas do livro de Losurdo, resumem a tese central desse autor: a democracia não é incompatível com a exclusão social, política e com a segregação racial. Melhor deixar que ele mesmo confirme esta leitura. Em seu diálogo com Tocqueville, conclui que "um país e um regime político são definidos democráticos independentemente da sorte dos excluídos, por mais amplo que possa ser o número e mais cruel a sua sorte".

Foi assim no começo, quando a democracia começava a engatinhar; mais tarde, quando o voto se tornou um direito universal e, finalmente, quando se transformou num regime um pouco mais justo, com garantias de alguns direitos sociais e econômicos. Não sem razão, Losurdo abre seu livro com os olhos voltados para o Oriente Médio, em particular para o Iraque, quando o bloqueio àquele país, imposto pelos Estados Unidos e seus aliados, implicou a desnutrição

“de $23 \%$ da população. A taxa de mortalidade infantil neste período duplicou: agora ronda 70 mil"; já está em causa a "sobrevivência de mais de um milhão de pessoas entre velhos, mulheres e crianças". "São tremendos os sofrimentos" impostos pelo bloqueio, mas "as atribulações do povo iraquiano não conseguem captar a compaixão internacional. E menos que nunca a da imprensa norte-americana que troa: "Se as Nações Unidas não quiserem impor uma zona proibida aos tanques (iraquianos), a América deverá impô-la unilateralmente".

Algumas páginas mais adiante, Losurdo demonstra que o imperialismo nunca saiu de cena. Desde a era colonial aos dias de hoje,

este sistema de relações internacionais celebra seus maiores triunfos mesmo no plano ideológico, rodeado que está por uma aura que consagra o seu caráter benéfico para o presente, o passado e o futuro. "Finalmente o colonialismo está de volta. Já era hora!", anunciou triunfalmente, o The New York Times, dando palavra ao historiador Paul Johnson.

Valendo-se de um arsenal de informações sobre os acontecimentos históricos que se desenrolam no presente, a crítica de Losurdo desnuda os amigos da Sociedade Aberta, para quem

os povos do Terceiro Mundo continuam a ser considerados meio crianças meio diabos, é justo que sejam severamente punidos pelos que são os únicos realmente capazes de entendimento e vontade, pelos adultos titulares do patria potestas, os países e as classes dirigentes do civilizado mundo capitalista.

Se, para Marx, "o capital nasce escorrendo sangue e lama por todos os poros, da cabeça aos pés", o colonialismo volta com mais sede de sangue do que nunca. Sua voracidade para saquear a "gentinha" pobre e ignorante da periferia capitalista, mitigada no breve período em que a Revolução de Outubro 
manteve sua bandeira hasteada, não tem mais limites. O processo de emancipação política, que freou o avanço do domínio colonial e o seu cortejo de intolerância racial e étnica, inverte-se com a queda o muro de Berlin, enfraquece-se e paralisase. Este é o balanço histórico realizado por Losurdo:

se os povos coloniais conquistaram os direitos políticos mediante a construção do Estado nacional independente (do qual eram considerados indignos e para o qual eram considerados incapazes), o esgotamento da soberania nacional, no Terceiro Mundo e nas zonas periféricas, é o modo concreto pelo qual se desenvolve hoje o processo de desemancipação, isto é, de liquidação dos direitos políticos que aqueles povos já haviam conquistado.

A conclusão que daí tira é de todos conhecida:

a maior parte da humanidade está prestes a ser excluída da "comunidade internacional", ou seja, para utilizar a linguagem e Popper, do círculo dos "Estados civilizados", como na época de ouro do colonialismo [...] Já emerge com clareza os contornos da "Nova Ordem Internacional": de um lado, aqueles a quem competem o direito e a obrigação de lançarem "operações de política internacional", de outro, os rogue States, os Estados-fora-da-lei; mais exatamente, os não-Estados, cujo comportamento ilegal deve ser abatido a qualquer custo e por qualquer meio. Neste tipo de Estado mundial aqui evocado compete ao Ocidente o monopólio da violência legítima, tornando explícito o processo de desemancipação que se consuma em prejuízo dos excluídos.

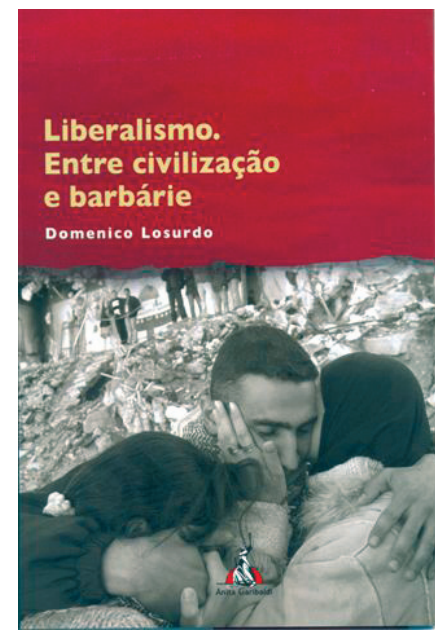

\section{LOSURDO, Domenico. Liberalismo.}

Entre civilização e barbárie.

São Paulo: Anita Garibaldi, 2008.

\section{Crítica da missão civilizadora}

Se vivos fossem Marx e Engels, certamente repensariam a idéia da missão civilizadora do capital. Coisa, aliás, que começaram a fazer em seus escritos de maturidade. Losurdo tem consciência disto, quando reconhece que se deve a Engels, "o princípio segundo o qual o proletariado vitorioso não pode impor nenhuma felicidade a nenhum povo estrangeiro sem com isto minar a sua própria vitória".

Embora reconheça que não faltam aos dois autores ambigüidades e oscilações, Losurdo, mais uma vez, repara que o Marx mais maduro rejeita

como "stirnerianismo proudhonianizado" a tese segundo a qual "toda nacionalidade, e as nações enquanto tais", seriam [...] preconceitos caducos [...]. A polêmica é tão áspera que Marx taxa como "cinismo de cretino" a posição de Proudhon, que se exprime em termos irônicos e depreciativos à aspiração da Polônia a sacudir o jugo do Império Russo para se constituir em Estado nacional. 
Ainda que faça poucas referências ao Marx de $O$ capital, Losurdo sabe que, nessa obra, nem de longe, vibra qualquer eco da idéia da missão civilizadora do Ocidente. Nela não existe nenhum vestígio de uma filosofia da história, a despeito das acusações que lhe são feitas pelos amigos da Sociedade Aberta da vida.

Mas é Lenin a quem Losurdo credita a liquidação da idéia da missão civilizadora da raça branca $[\ldots]$, ao mesmo tempo, da visão unilinear do processo histórico própria da filosofia burguesa da história, que assenta no pressuposto da nítida distinção entre a área civilizada e a área da barbárie e do atraso por outro.

Mais claramente: "já em Marx e Engels a visão unilinear do processo histórico começa a cair em crise pela atenção prestada à questão nacional. Mas esta só se torna central em Lenin".

Para saber as razões por que Losurdo credita a Lenin e não a Marx e Engels a centralidade dessa questão, o leitor está convidado a descobri-las por conta própria. Adiante-se apenas que o revolucionário russo sofreu na pele o cerco imperialista contra a Revolução de Outubro. Grande parte do seu país, aos olhos preconceituosos do Ocidente, ainda estava imerso nas trevas da "desrazão". As razões de tudo isso estão escancaradas nas páginas de Liberalismo. Entre civilização e barbárie. Venha conhecê-las!

Francisco José Soares Teixeira é professor de Economia Política da Universidade Estadual do Ceará (UECE) e autor, entre outras obras, de Trabalho e valor: contribuição para a critica da razão econômica (2004); em co-autoria: Marx no século XXI (Cortez, no prelo). @ - acopyara@uol.com.br 